\title{
Expression of Foxp3 in non-small cell lung cancer patients is significantly higher in tumor tissues than in normal tissues, especially in tumors smaller than $30 \mathrm{~mm}$
}

\author{
YASUNORI ISHIBASHI, SHIGEBUMI TANAKA, KOHEI TAJIMA, \\ TAKESHI YOSHIDA and HIROYUKI KUWANO
}

\begin{abstract}
Department of General Surgical Science and the 21st Century COE Program, Gunma University
Graduate School of Medicine, 3-39-22 Showa-machi, Maebashi, Gunma 371-8511, Japan
\end{abstract}

Received November 15, 2005; Accepted January 9, 2006

\begin{abstract}
Active suppression by $\mathrm{CD} 4{ }^{+} \mathrm{CD} 25^{+} \mathrm{T}$ regulatory cells ( $\mathrm{T}$ regs) plays an important role in the down-regulation of $\mathrm{T}$ cell responses to foreign and self-antigens. Thus far, the potential role of $\mathrm{T}$ regs in human tumors has been reported. $\mathrm{T}$ reg-mediated suppression of antitumor immune responses may partly explain the poor clinical response to vaccine-based immunotherapy for human cancer. The forkhead transcription factor Foxp3 is a critical regulator of T regs development and function. Foxp3 represents a specific marker for the T regs. In this study, we measured the Foxp3 mRNA expression in tumors and in normal tissues from 46 patients with non-small cell lung carcinoma (NSCLC), and tumor tissues showed a significantly higher expression of Foxp 3 mRNA than normal tissues. The expression of Foxp 3 mRNA and the tumor diameter were inversely proportional. These results suggest that $\mathrm{T}$ regs expressing Foxp3 selectively accumulate in tumor tissues of NSCLC and contribute to antitumor immune dysfunction, especially in the early stages.
\end{abstract}

\section{Introduction}

Lung cancer is one of the most significant, avoidable causes of death around the world. It is the most widespread carcinoma with a very poor prognosis, and it is the leading cause of cancer death in both developed and developing countries (1). Most cancer patients do not develop a satisfactory immunological antitumor response, implicating the existence of tumor-specific immune evasion strategies, including the down-regulation of components of the antigen processing and antigen presentation and the induction of tumor antigen-specific $\mathrm{T}$ cell tolerance

Correspondence to: Dr Yasunori Ishibashi, Department of General Surgical Science, Gunma University Graduate School of Medicine, 3-39-22 Showa-machi, Maebashi, Gunma 371-8511, Japan

E-mail: yisibasi@med.gunma-u.ac.jp

Key words: Foxp3, T regulatory cells, immunosuppression, nonsmall cell lung cancer through normal pathways of self-tolerance generation (2-5). Although the induction of autoimmune disease involves many factors, the defining event is the loss of T cell tolerance to selfantigens. Tolerance is maintained in part by negative selection of autoreactive T cells in the thymus and by induction of anergy in the periphery $(6,7)$. However, these two mechanisms alone are insufficient to preserve the tolerant state. Recently, the crucial role of $\mathrm{T}$ regs in suppression of responses to self-Ags has been demonstrated in both mice and humans (8-10). Active suppression by $\mathrm{T}$ regs plays an important role in the downregulation of $\mathrm{T}$ cell responses to foreign and self-antigens.

It has been previously reported that Foxp3 is a key regulatory gene for the development of $\mathrm{T}$ regs (11). Foxp3 is a transitional repressor required for the development and function of T regs (12). Deficiency of Foxp3 leads to autoimmune diseases including X-linked immune dysfunction, polyendocrinopathy and enteropathy in humans and scurfy in mice. Although CD4 and CD25 partially identify the T reg compartment, Foxp3 is currently the most definitive marker of regulatory function (12-14). It has been reported that $\mathrm{T}$ regs exist in increased proportions in the tumor-infiltrating lymphocytes (TIL) of patients with NSCLC (15) and other tumors (16-19).

We have studied whether tumor-infiltrating $\mathrm{T}$ regs influence the clinicopathological characteristics of NSCLC patients by comparing the Foxp3 expression in tumor tissues and normal lung tissues. In this study, we showed that tumor tissues contain a higher expression of Foxp3 than normal lung tissues. Moreover, we found that the expression of Foxp3 and tumor diameter were inversely proportional, suggesting that $\mathrm{T}$ regs accumulate in tumor tissues and could contribute to the progression of NSCLC, especially in the early stage of the tumor. These $\mathrm{T}$ regs may play a role in inducing and/ or maintaining immune tolerance to tumors in patients with NSCLC, and the manipulation of this subpopulation could be an important component of cancer therapy.

\section{Materials and methods}

Patient population. Forty-six patients with primary NSCLC and without neoadjuvant therapy were selected from the Department of General Surgical Science, Gunma University Graduate School of Medicine (Maebashi, Japan), between 
September 1999 and February 2004. The group included 33 men and 13 women aged $36-84$ years (mean age, 65.2 years). Tumor stage and disease grade were classified according to the fifth edition of the TNM classification of the International Union Against Cancer (UICC). Written informed consent to participate in the study was obtained from each patient according to the ethical guidelines of our university. Tumor tissues and normal tissues were collected at the time of surgery and processed by sterile mechanical dissection. Normal tissues were obtained from non-inflammatory tissues which were located as far away from tumor tissues as possible. Obtained tissues were cryopreserved for further analysis.

$R N A$ extraction and quantitative real-time RT-PCR analysis. Total RNA $(1 \mu \mathrm{g})$ extracted with RNeasy Mini Kit (Qiagen, Tokyo, Japan) was reverse transcribed using $2.5 \mu \mathrm{M}$ random hexamers (Takara Bio, Otsu, Japan), 4 units of Omniscript Reverse Transcriptase (Qiagen) mixed with $2 \mu 1$ of $10 \mathrm{X}$ Buffer RT (Qiagen), $2 \mu \mathrm{l}$ of dNTP Mix (Quiagen) at $5 \mathrm{mM}$ each and 10 units of RNase inhibitor (Takara Bio), and nuclease free water (Invitrogen Corp., Carlsbad, CA) in a final volume of $20 \mu \mathrm{l}$. One-twentieth of the RT reaction (50 ng of RNA converted to cDNA) was used as a template for the PCR step using TaqMan Universal PCR Master Mix, as recommended by the supplier (Applied Biosystems). Quantitative real-time PCR was performed using Assays-on-Demand and an ABI PRISM $^{\circledR} 7000$ Sequence Detection System on human target genes, Foxp3 (assay IDs Hs00203958_m1; Applied Biosystems, Foster City, CA), and Pre-Developed TaqMan ${ }^{\circledR}$ Assay Reagents Endogenous Human beta actin (Applied Biosystems). Primers, probes, and cDNA were added to the TaqMan Universal PCR Master Mix (Applied Biosystems), which contained all reagents for PCR. The PCR conditions included 1 cycle at $50^{\circ} \mathrm{C}$ for $2 \mathrm{~min}, 1$ cycle at $95^{\circ} \mathrm{C}$ for $10 \mathrm{~min}, 40$ cycles at $95^{\circ} \mathrm{C}$ for $15 \mathrm{sec}$ and $60^{\circ} \mathrm{C}$ for $1 \mathrm{~min}$. PCR products were measured continuously with an ABI PRISM 7000 Sequence Detection System (Applied Biosystems). The relative amount of Foxp3 transcript was normalized to the amount of $B$-actin transcript in the same cDNA.

Statistical analysis. Continuous variables were compared using Student's t-test and Mann-Whitney U test. Differences between the clinical parameters of the two groups were determined by the $\chi^{2}$ test. Significance of the difference in survival rates was determined by the log-rank (Mantel-Cox) test. Statistical significance was assumed for $\mathrm{p}$-values $<0.05$.

\section{Results}

Expression of Foxp3 mRNA level and ratio in tumor tissues and normal tissues in NSCLC patients. Patients' clinical characteristics are described in Table I. A significantly higher mean expression level of Foxp3 was detected in tumor tissues than in normal tissues $(\mathrm{p}<0.01$; Fig. $1 \mathrm{~A})$. Comparing the two groups of tumors, which were less than or greater than $30 \mathrm{~mm}$ in diameter, a significant difference was observed only in smaller tumors of $30 \mathrm{~mm}$ or less $(\mathrm{p}<0.01$; Fig. 1B). A significantly higher mean expression level was detected in tissues of tumors smaller than $30 \mathrm{~mm}$ compared to those larger than $30 \mathrm{~mm}(\mathrm{p}<0.05$; Fig. 1B) although no significant
Table I. Clinical characteristics and distribution of patients according to their Foxp3 expression ratio.

\begin{tabular}{|c|c|c|c|c|}
\hline Parameter & $\begin{array}{l}\text { Total } \\
(n=46)\end{array}$ & $\begin{array}{l}\text { Positive }^{\mathrm{a}} \\
(\mathrm{n}=27)\end{array}$ & $\begin{array}{l}\text { Negative }^{a} \\
(n=19)\end{array}$ & P-value ${ }^{b}$ \\
\hline Age $\left(\right.$ years) ${ }^{c}$ & $65.2 \pm 9.6$ & $65.5 \pm 10.8$ & $64.8 \pm 8.1$ & 0.828 \\
\hline \multicolumn{5}{|l|}{ Gender } \\
\hline Male & 33 & 19 & 14 & 0.806 \\
\hline Female & 13 & 8 & 5 & \\
\hline \multicolumn{5}{|l|}{ Histology } \\
\hline $\begin{array}{l}\text { Adeno- } \\
\text { carcinoma }\end{array}$ & 31 & 18 & 13 & 0.084 \\
\hline $\begin{array}{l}\text { Squamous cell } \\
\text { carcinoma }\end{array}$ & 10 & 4 & 6 & \\
\hline $\begin{array}{l}\text { Large cell } \\
\text { carcinoma }\end{array}$ & 5 & 5 & 0 & \\
\hline \multicolumn{5}{|l|}{ Differentiation } \\
\hline Well & 9 & 6 & 3 & 0.382 \\
\hline Moderate & 20 & 11 & 9 & \\
\hline Poor & 11 & 4 & 7 & \\
\hline
\end{tabular}

Tumor status

$\begin{array}{lrrr}\text { pT1 } & 13 & 11 & \\ \text { pT2 } & 26 & 12 & 14 \\ \text { pT3 } & 2 & 1 & \\ \text { pT4 } & 5 & 3\end{array}$

$\mathrm{N}$ status

$\begin{array}{llll}\text { N0 } & 27 & 17 & 10\end{array}$

0.625

$\mathrm{N} 1 \quad 5$

$\mathrm{N} 2 \quad 13$

3

6

N3

M status

M0

M1

Staging

I 24

II 2

III 17

IV

3

$\begin{array}{rr}15 & 9 \\ 1 & 1 \\ 8 & 9 \\ 3 & 0\end{array}$

Lymphatic invasion

\begin{tabular}{lrrrr}
+ & 24 & 14 & 10 & 0.824 \\
- & 20 & 11 & 9 & \\
Vessel invasion & & & & \\
+ & 20 & 13 & 7 & 0.395 \\
- & 23 & 12 & 11 & \\
Pleural invasion & & & & \\
+ & 17 & 10 & 7 & 0.912 \\
- & 28 & 16 & 12 & \\
\hline
\end{tabular}

${ }^{\mathrm{a}}$ Over 2 times expression ratio classified as positive. ${ }^{\mathrm{b}} \lambda^{2}$ test. ${ }^{\mathrm{c} D a t a}$ are values for average \pm SD. 
A

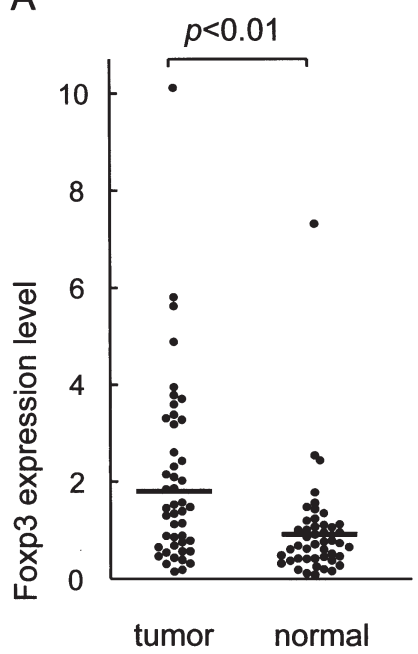

C

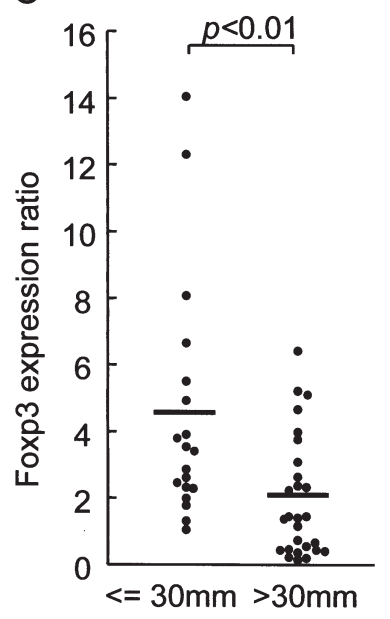

$E$

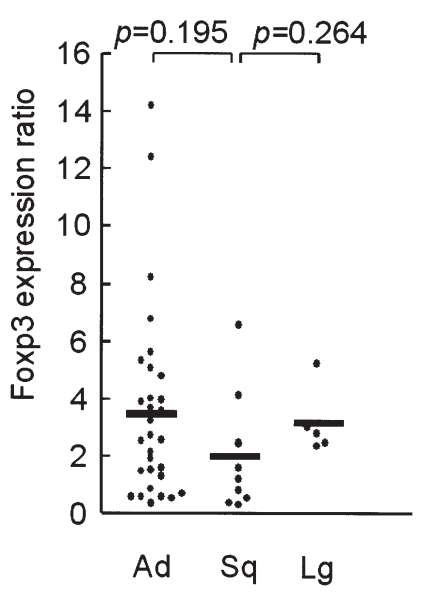

difference was detected in normal tissues according to the tumor diameter. Accordingly, the expression ratio (relative expression level in tumor tissues compared to that in normal tissues in the same patients) was significantly higher in the group of tumors smaller than $30 \mathrm{~mm}(\mathrm{p}<0.01$; Fig. 1C). $\mathrm{T}$ factor classification is reflected by tumor diameter. Similarly, the expression level with pT1 in tumor tissues compared to
B

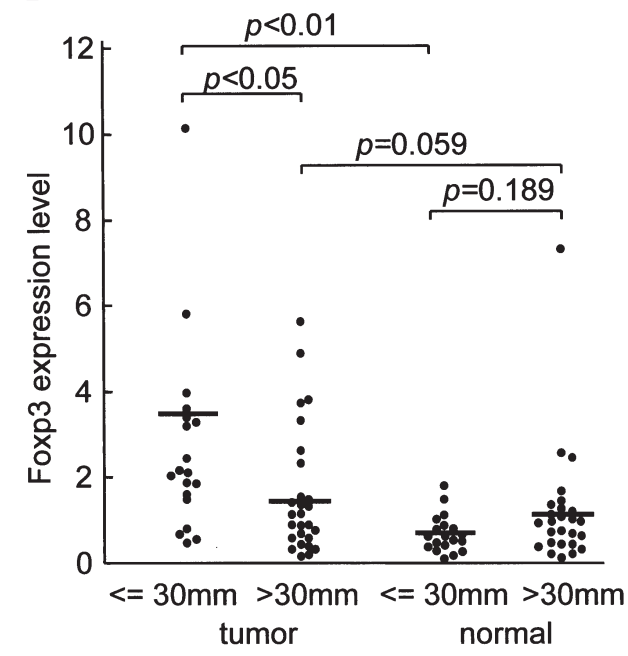

D

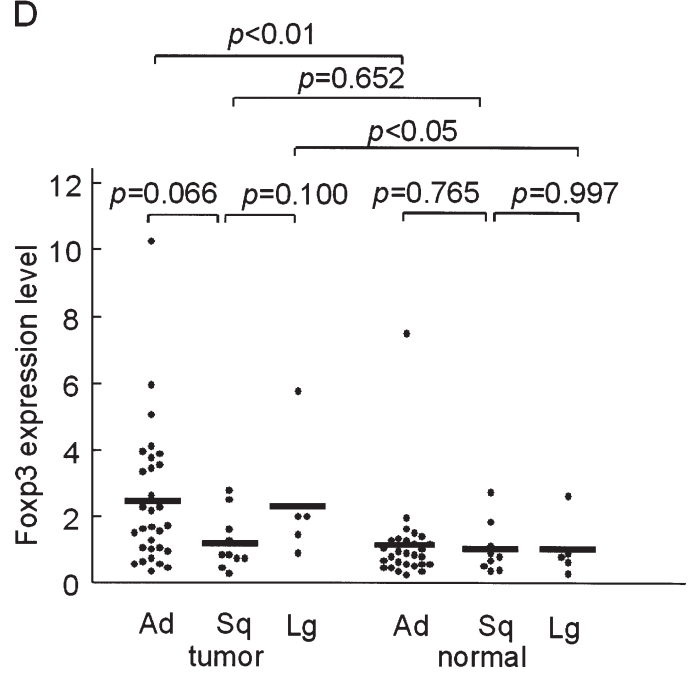

Figure 1. Scatter plots of expression level and ratio of Foxp3 mRNA in NSCLC. (A), Expression level in tumor and normal tissue. (B), Expression level in tumor and normal tissue according to tumor diameter. (C), Expression ratio according to tumor diameter. (D), Expression level in tumor and normal tissue according to their histology. (E), Expression ratio according to their histology. Ad, adenocarcinoma; Sq, squamous cell carcinoma; Lg, large cell carcinoma. Closed circles and bars represent values for individual patients and average values for patient groups, respectively.

normal tissues and expression ratio with pT1 compared to over pT2 were significantly high $(\mathrm{p}<0.05$ and $\mathrm{p}<0.01$, respectively; data not shown). Although the expression level in tumor tissues was significantly higher than that in normal tissues in adenocarcinoma and large cell carcinoma $(\mathrm{p}<0.01$ and $<0.05$, respectively; Fig. 1D), no significant mean expression level was detected in squamous cell carcinoma. A tendency towards a lower mean expression level in tumor tissues was detected in squamous cell carcinoma compared to adenocarcinoma ( $\mathrm{p}=0.066$; Fig. 1D). Expression ratios were not significant according to histopathology (Fig. 1E). Because 9 of the 10 cases of squamous cell carcinoma were larger than $30 \mathrm{~mm}$ in diameter, we next studied the expression levels and ratios with tumors larger than $30 \mathrm{~mm}$ according to 


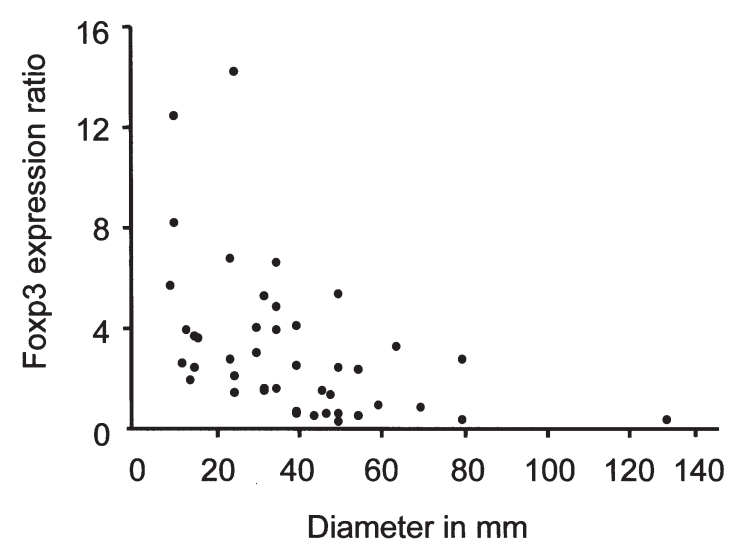

Figure 2. Correlation between expression ratio and tumor diameter in NSCLC. Correlation coefficient is $-0.441, \mathrm{p}<0.01$. Negative correlation is observed.

histopathology, considering that squamous cell carcinoma showed no tendency towards a lower expression level (data not shown). A negative correlation was observed between the expression ratio and tumor diameter (correlation coefficient -0.441, p $<0.01$; Fig. 2).

Relationship between the expression ratio of Foxp 3 mRNA and clinicopathological factors. Correlation between clinicopathological factors and the Foxp3 expression ratio is summarized in Table I. Two groups were compared according to an expression ratio two times greater or less. There was no significant difference in clinicopathological factors and the expression ratio. When groups demonstrated an expression ratio of 1.5-2.5, no significant difference was observed (data not shown). Five-year survival rates and expression ratios showed no statistically significant difference (data not shown).

\section{Discussion}

Naturally occurring $\mathrm{CD} 4{ }^{+} \mathrm{CD} 25^{+} \mathrm{T}$ cells originate from the thymus and play an important role of the maintenance of peripheral tolerance by suppression of autoreactive T-cell populations. However, regulatory cells can have beneficial as well as harmful effects. Although they prevent a variety of autoimmune and inflammatory diseases, they concomitantly inhibit antitumor immune reactions by suppressing tumorspecific T-cell responses. Patients with cancer have an increased number of peripherally circulating and tumor site $\mathrm{T}$ regs $(15-17,20)$. It has been proposed that mechanisms underlying autoimmunity and tumor immunity are linked (21). It has been reported that carcinogen-induced tumors elicit both concomitant antitumor immunity and immune suppression $(22,23)$.

The aim of this study was to investigate the influence of tumor-infiltrating $\mathrm{T}$ regs in TIL on clinicopathological characteristics of NSCLC patients. Recent reports showed that $\mathrm{T}$ regs constitutively express the transcription factor Foxp3 $(11,13)$, so a high Foxp3 expression can be considered as an accumulation of $\mathrm{T}$ regs.

We have used normal lung tissues obtained from NSCLC patients for the first time to evaluate the accumulation of $\mathrm{T}$ regs in tumor tissues while previous reports used peripheral blood as a control $(15,20)$. In this study, by investigating the expression ratio, the increase of $\mathrm{T}$ regs in tumor tissues compared to normal lung tissues could be evaluated more appropriately among patient groups with different clinical characteristics. We demonstrated that $\mathrm{T}$ regs accumulate more in tumor tissues than in normal lung tissues in NSCLC patients. This accumulation was observed especially in tumors smaller than $30 \mathrm{~mm}$, and a negative correlation was observed between $\mathrm{T}$ reg accumulation and tumor diameter.

It has been reported that a higher percentage of tumorinfiltrating $\mathrm{T}$ regs was observed in advanced stages than in early stages of ovarian carcinoma and gastric cancer patients $(17,18)$, and the increases of the percentage predicted poor survival in ovarian carcinoma. In NSCLC, previous studies have reported an increase in the percentage of $\mathrm{T}$ regs in tumor tissues compared to peripheral blood $(15,20)$. In this study, we found the Foxp3 expression was higher in tumor tissues than in normal tissues, which means that $\mathrm{T}$ regs accumulate in tumor tissues. On this point, our data are in accordance with these reports, but we found no correlations between the Foxp3 expression in tumor tissues and survival, stages, or clinicopathological factors of NSCLC.

Based on the cytokine synthesis, $\mathrm{CD}^{+} \mathrm{T}$ cells can often be classified into Th1 and Th2. In the same way, cytolytic $\mathrm{CD}^{+}$effector cells fall into two subpopulations, Tc1 and Tc2 $(24,25)$. These cells play important immunoregulatory roles. Some recent studies have demonstrated that an elevated level of type 2 cytokines contributes to the ability of cancer cells to escape immunosurveillance. Norimasa et al investigated the impacts of Th1, Th2, Tc1 and Tc2 on tumor immunity in NSCLC (26). They have reported that the Th1-to-Th2 and Tc1-to-Tc2 ratios in the TIL were significantly different according to tumor size and histology. These ratios were more significantly elevated in the squamous cell carcinoma than adenocarcinoma. The group of tumors over $30 \mathrm{~mm}$ in size had a significantly elevated Th1-to-Th2 ratio. Norimasa et al have suggested that the host immunoreactivity against the tumor differs according to these clinical characteristics. The histology may reflect the modality of the antigen, and the tumor size may reflect the quantity of antigens. There are few reports referring to $\mathrm{T}$ regs and the Th1-to-Th2 or Tc1-to-Tc2 ratios in cancer patients, so it is not clear whether Th1-to-Th2 or Tc1-to-Tc2 ratios and immunosuppression by $\mathrm{T}$ regs are linked or not.

Our data revealed that there was a tendency for a higher mRNA expression level of Foxp3 in adenocarcinoma but no different expression ratio and a significantly higher expression level and ratio in the group which included tumors over $30 \mathrm{~mm}$. The Foxp3 expression level reflects the density of $\mathrm{T}$ regs. It does not mean that the decrease of Foxp3 expression level in inverse proportion to tumor diameter equals the decrease of the number of $\mathrm{T}$ regs from a point of total tumor-infiltrating $\mathrm{T}$ regs. Although $\mathrm{T}$ regs may accumulate in tumor tissues from the early stages, the tumor expansion may be more rapid than the increasing number of $\mathrm{T}$ regs.

Our data suggest that the immunosuppressive mechanisms induced by $\mathrm{T}$ regs in NSCLC patients may have a relationship to tumor volume. The mechanisms especially may have an impact on the stage at which the tumor occurs. 
In summary, $\mathrm{T}$ regs accumulate in tumor tissues in NSCLC, causing an especially high density in tissues from smaller tumors. As these $\mathrm{T}$ regs may be involved in carcinogenesis, future strategies should be directed toward controlling their function.

\section{References}

1. Travis WD, Lubin J, Ries L and Devesa S: United States lung carcinoma incidence trends: declining for most histologic types among males, increasing among females. Cancer 15: 2464-2470, 1996.

2. Strand S and Galle PR: Immune evasion by tumors: involvement of the CD95 (APO-1/Fas) system and its clinical implications (Review). Mol Med Today 4: 63-68, 1998.

3. Yang Y, Huang CT, Huang X and Pardoll DM: Persistent Toll-like receptor signals are required for reversal of regulatory $\mathrm{T}$ cellmediated CD8 tolerance. Nat Immunol 5: 508-515, 2004.

4. Restifo NP, Esquivel F, Kawakami Y, Yewdell JW, Mule JJ, Rosenberg SA and Bennink JR: Identification of human cancers deficient in antigen processing. J Exp Med 177: 265$272,1993$.

5. Lee PP, Yee C, Savage PA, Fong L, Brockstedt D, Weber JS, Johnson D, Swetter S, Thompson J, Greenberg PD, Roederer M and Davis MM: Characterization of circulating T cells specific for tumor-associated antigens in melanoma patients. Nat Med 5: 677-685, 1999.

6. Sakaguchi S: Regulatory T cells: key controllers of immunologic self-tolerance (Review). Cell 101: 455-458, 2000.

7. Van Parijs L and Abbas AK: Homeostasis and self-tolerance in the immune system: turning lymphocytes off (Review). Science 280: 243-248, 1998.

8. Ethan S: Regulatory T cells in autoimmunity (Review). Annu Rev Immunol 18: 423-449, 2000.

9. Kevin JM and Fiona P: Regulatory T cells in the control of immune pathology (Review). Nat Immunol 2: 816-822, 2001

10. Bach JF: Organ-specific autoimmunity. Immunol Today 16: 353-355, 1995 .

11. Shohei H, Takashi N and Sakaguchi S: Control of regulatory $\mathrm{T}$ cell development by the transcription factor Foxp3. Science 299: 1057-1061, 2003.

12. Khattri R, Cox T, Yasayko SA and Ramsdell F: An essential role for Scurfin in $\mathrm{CD}^{+} \mathrm{CD} 25^{+} \mathrm{T}$ regulatory cells. Nat Immunol 4: 337-342, 2003.

13. Fontenot JD, Gavin MA and Rudensky AY: Foxp3 programs the development and function of $\mathrm{CD} 4{ }^{+} \mathrm{CD} 25^{+}$regulatory $\mathrm{T}$ cells. Nat Immunol 4: 330-336, 2003.

14. Gambineri E, Torgerson TR and Ochs HD: Immune dysregulation, polyendocrinopathy, enteropathy and $\mathrm{X}$-linked inheritance (IPEX), a syndrome of systemic autoimmunity caused by mutations of FOXP3, a critical regulator of T-cell homeostasis (Review). Curr Opin Rheumatol 15: 430-435, 2003.
15. Woo EY, Yeh H, Chu CS, Schlienger K, Carroll RG, Riley JL, Kaiser LR and June CH: Regulatory T cells from lung cancer patients directly inhibit autologous $\mathrm{T}$ cell proliferation. $\mathrm{J}$ Immunol 168: 4272-4276, 2002.

16. Liyanage UK, Moore TT, Joo HG, Tanaka Y, Herrmann V, Doherty G, Drebin JA, Strasberg SM, Eberlein TJ, Goedegebuure PS and Linehan DC: Prevalence of regulatory $\mathrm{T}$ cells is increased in peripheral blood and tumor microenvironment of patients with pancreas or breast adenocarcinoma. J Immunol 169: 2756-2761, 2002.

17. Curiel TJ, Coukos G, Zou L, Alvarez X, Cheng P, Mottram P, Evdemon-Hogan M, Conejo-Garcia JR, Zhang L, Burow M, Zhu Y, Wei S, Kryczek I, Daniel B, Gordon A, Myers L, Lackner A, Disis ML, Knutson KL, Chen L and Zou W: Specific recruitment of regulatory $\mathrm{T}$ cells in ovarian carcinoma fosters immune privilege and predicts reduced survival. Nat Med 10: 942-949, 2004.

18. Ichihara F, Kono K, Takahashi A, Kawaida H, Sugai H and Fujii H: Increased populations of regulatory T cells in peripheral blood and tumor-infiltrating lymphocytes in patients with gastric and esophageal cancers. Clin Cancer Res 9: 4404-4408, 2003.

19. Sasada T, Kimura M, Yoshida Y, Kanai M and Takabayashi A: $\mathrm{CD} 4{ }^{+} \mathrm{CD} 25^{+}$regulatory $\mathrm{T}$ cells in patients with gastrointestinal malignancies: possible involvement of regulatory $\mathrm{T}$ cells in disease progression. Cancer 98: 1089-1099, 2003.

20. Woo EY, Chu CS, Goletz TJ, Schlienger K, Yeh H, Coukos G, Rubin SC, Kaiser LR and June CH: Regulatory CD4(+)CD25(+) $\mathrm{T}$ cells in tumors from patients with early-stage non-small cell lung cancer and late-stage ovarian cancer. Cancer Res 61: 4766-4772, 2001.

21. Turk MJ, Wolchok JD, Guevara-Patino JA, Goldberg SM and Houghton AN: Multiple pathways to tumor immunity and concomitant autoimmunity (Review). Immunol Rev 188: 122-135, 2002.

22. North RJ and Bursuker I: Generation and decay of the immune response to a progressive fibrosarcoma. I. Ly-1+2- suppressor T cells down-regulate the generation of Ly-1-2+ effector T cells. J Exp Med 159: 1295-1311, 1984.

23. Gorelik E: Concomitant tumor immunity and the resistance to a second tumor challenge. Adv Cancer Res 39: 71-120, 1983.

24. Mosmann TR and Sad S: The expanding universe of T-cell subsets: Th1, Th2 and more (Review). Immunol Today 17: 138-146, 1996.

25. Carter LL and Dutton RW: Type 1 and type 2: a fundamental dichotomy for all T-cell subsets. Curr Opin Immunol 8: 336-342, 1996.

26. Ito N, Nakamura H, Tanaka $\mathrm{Y}$ and Ohgi S: Lung carcinoma: analysis of T helper type 1 and 2 cells and T cytotoxic type 1 and 2 cells by intracellular cytokine detection with flow cytometry. Cancer 85: 2359-2367, 1999. 